\title{
The Sensitivity of Capital Use to Price in Higher Education
}

by

Malcolm Getz and John J. Siegfried

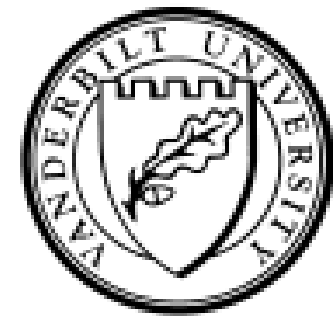

Working Paper No. 04-W05

February 2004

DEPARTMENT OF ECONOMICS

VANDERBILT UNIVERSITY

NASHVILLE, TN 37235

www.vanderbilt.edu/econ 
January 9, 2004

The Sensitivity of Capital Use to Price in Higher Education ${ }^{1}$

By Malcolm Getz and John J. Siegfried

College and university faculty-to-student ratios are important. They are used by prospective students as an indicator of the attention they might receive from faculty if they were to enroll. University budget officers use them as a benchmark for unit costs, often so myopically that one would think faculty salaries are the only cost of higher education. Economists study them as an influence on unit costs in higher education. In earlier work on the costs of higher education, the present authors found that there is a positive relationship between the faculty to student ratio and cost per student. (Clotfelter, Ehrenberg, Getz, and Siegfried, 1991).

In practice, the share of labor costs in higher education is only marginally higher than it is in the economy more generally (about 80 percent of value added compared to labor's 70 percent share in the overall economy). But while the private for-profit sector devotes considerable effort to fine-tuning the appropriate amount of capital for its production processes, decision-makers involved in the production of higher education often act as if their product is produced in an open field, with no capital requirement whatsoever.

There are a number of reasons capital costs are frequently neglected in educational production decisions. For one, historic U.S. fund-accounting standards for not-for-profit educational institutions do not require the maintenance of a capital account. Depreciation of physical assets has not been systematically computed and deducted from 
revenues on the statement of revenues and expenses (known as an income statement in the for-profit world). Consequently, the cost of capital inputs has affected management decision-making only haphazardly. The cost of capital was counted and appeared on the statement of revenues and expenses if the capital was not owned, but instead was rented from outside agents. Just part of the cost of capital was counted if the capital was owned by the institution, but financed by borrowing. Then the interest expense appeared on the books, but depreciation of the principal did not. Finally, when the capital was owned by the institution and purchased outright from its own accumulated surplus, from its endowment, or from earmarked tax sources, neither the depreciation of the capital investment nor its opportunity cost would be recognized as a current expense by conventional educational fund accounting (Winston, 1993). If it is out-of-sight, it is usually out-of-mind. ${ }^{1}$

Secondly, most substantial capital investments in terms of dollar value on college and university campuses consist of new buildings, and these are frequently made when the opportunity arises rather than on the basis of optimal timing carefully calibrated to anticipate future needs. At public institutions capital expenditures often draw on a state government capital expenditure budget, and therefore compete with capital projects proposed by other government entities. At private institutions major capital expenditures are usually financed, at least partially, by a fund raising campaign or a single large gift. Opportunities to tap a government capital budget or to attract private donations to fund a building do not always mesh well with capital needs as articulated by an educational production function. Thus, the myopic focus on the costs of labor by college and 
university administrators may correctly reflect attention to the input decision over which they have most control.

In this paper we offer a rudimentary attempt to estimate whether not-for-profit colleges and universities in the U.S. adjust the amount of building space they consume to relative prices. Holding quality constant, faculty are traded in a national market. Most professors expect to relocate if they change jobs. If faculty are mobile on the margin and supply to particular institutions responds to earnings differentials, other job characteristics held constant, in the long run the price of faculty (adjusted for cost of living differences) will be equalized across institutions.

Not so, however, for building space, which is purchased largely in local markets and cannot easily be traded. Although some inputs into the construction of buildings are traded over an extensive geographic area (for example, steel beams are produced in only a half dozen states in the U.S.), many construction inputs are heavy relative to their value (for example, ready-mix concrete), and are not traded over a wide geographic area. Even those construction inputs, such as steel beams, that are shipped long distances are likely to cost various colleges and universities different amounts once the substantial transportation costs from a few points of origin are added to form the delivered cost of the materials. Mobility impediments in construction labor markets lead to further differences in the cost of constructing square feet of building space among colleges and universities. Consequently, we hypothesize that the cost of buildings relative to the cost of faculty differs across colleges and universities.

The basic premise of the analysis is that in higher education, low student to square feet of building space ratios are desired as a feature and interpreted as a symptom of 
quality. Schools that offer larger dormitory rooms, more public congregation space, larger classrooms and laboratories, expanded libraries, more recreation facilities, etc. are perceived as offering higher quality educational services. Building space is a productive input into higher education. As such, we would expect a cost minimizing college or university to purchase it to the extent where its marginal cost is balanced against the marginal cost of alternative inputs. Because the most important alternative input is faculty, and faculty are purchased largely in a national marketplace, most of the difference in the ratio of incremental cost of space relative to the incremental cost of faculty arises because of differences in the cost of building space.

There is scope for substitution of capital for labor. Where capital is more expensive, classrooms can be used in the evenings, weekends, and summers. Institutions can invest more in design, maintenance, and support of facilities so as to achieve higher levels of utilization per square foot. Libraries can move seldom-used materials to remote storage. Parking can be moved further from congested areas. Some services can be contracted out so that office space, maintenance facilities, and storage are off-site in noninstitutional facilities. All of these measures might be used to achieve higher student to square foot ratios when the price of buildings is higher.

In this exploratory effort we investigate whether those higher education institutions that confront relatively higher costs of buildings produce their education with relatively fewer square feet of building space per student. In short, are the students at New York University and Columbia University in New York City more crowded than those out on the prairie at Kansas State University and Grinnell College, which is sometimes dubbed the "college in a cornfield?" If residual claimant incentives were 
sufficient to induce colleges and universities to arrange their production inputs so as to minimize costs, we would expect to see a systematic relationship between square feet per student (the capital to output ratio) and the relative price of capital. ${ }^{2}$

\section{The Empirical Approach}

We employ a cross-sectional approach in order to observe the relationship between space utilization and its cost in higher education. Our sample consists of data from 210 colleges and universities for the 1993-94 academic year. Many of the colleges and universities in the sample have different missions.

To deal with the heterogeneity among observations in our sample caused by differing institutional missions we group them on the basis of their Carnegie Foundation for the Advancement of Teaching classification. There are four types of institutions in our sample: 33 private selective undergraduate liberal arts colleges; 27 private comprehensive universities, 55 public comprehensive universities; and 95 two-year colleges. We analyze the relationship between the ratio of students per square feet of educational space and the cost of that space separately for each group. We do not analyze the students per square foot for research and doctoral universities because they are too heterogeneous, some encompass medical centers or major labs that are not related to enrollments.

We expect to find that public comprehensive universities and two-year colleges are more sensitive to the relative prices of their inputs than are selective liberal arts colleges or private comprehensive universities. The 50 or so highly selective private liberal arts colleges are among the wealthiest of the 4,200 institutions of higher education 
in the U.S., and we draw our sample from is group. These wealthy institutions often attract large gifts from successful alumni or friends, many of which are used to construct facilities that subsequently bear the name of the donor. The private comprehensive universities, although holding less wealth, may also depend on donors but to a lesser extent than the liberal arts colleges. It is unlikely that donor willingness to contribute and an institution's space needs based on a balancing of the incremental cost of various inputs into the educational production function would harmonize well. Thus we do not expect to observe the building programs of the wealthier colleges and universities to reflect a minimization of costs on the margin. ${ }^{3}$

On the other hand, public comprehensive universities and two-year colleges usually possess little endowment or accumulated surplus (the not-for-profit name for retained earnings) that could provide discretion in investment decisions. Building space is more likely to be constructed when enrollment or program changes make it essential, not when unexpected donations are received. Although state colleges and universities often have to compete against potential investments in other public infrastructure, they usually can justify such projects only when they are needed so desperately that the institution's administration or the state government has little choice. What is likely to vary among these institutions, however, is the cost minimizing mix between physical facilities and faculty.

In addition to segmenting our empirical tests by the mission of the institutions, we attempt to control for other heterogeneity among the institutions that would naturally cause the student to square feet of building space ratio to differ among them. First, there may be economies of scale in the production of college and university education (Getz, 
Siegfried, and Zhang, 1991). Certain kinds of space can be shared by students or used at different times by different students. Capital utilization depends, in part, on having sufficient enrollment to fully utilize those buildings which come only in lumpy increments, such as basketball courts. We include both enrollment and enrollment squared in our estimated regressions in order to allow for a non-linear relationship between the output to capital (student to square feet) ratio and the scale of operation.

A second consideration relevant to any study of cost minimization is whether or not the institutions from which data are assembled are in equilibrium. A long-run average cost curve is described by combinations of output and cost if and only if the decision-making units are operating at points where short-run cost curves are tangent to the long-run planning curve. This occurs only when they are in equilibrium (Getz, Siegfried, and Zhang, 1991).

In the present context, if an institution has experienced unexpected increases in enrollment to which it has not had an opportunity to adjust, the student to square feet ratio would rise above the targeted level until such time that the institution could either rent additional square feet or construct sufficient additional building space to lower the ratio back down to the target. On the other hand, if an institution had recently experienced unanticipated declining enrollments, its student to square feet ratio would fall below its target until the institution could either escape from existing leases or retire some existing structures. Under such conditions we would observe a student to square feet ratio below long-run equilibrium. We control for disequilibrium in 1993-94 by including a measure of the rate of change in enrollment from 1986-87 through 1993-94. We expect to observe a higher student to square feet ratio the faster enrollment has 
increased. The implicit assumption is that enrollment is expected to change at the same rate at all institutions, perhaps based on predictable demographic evolution.

In order to control for differences in residence facilities across institutions we include a measure of the number of dormitory rooms per student on campus. Absent a control for residential space we would observe a misleadingly low student to square feet ratio at institutions that provide more dormitory space for students.

We consider public and private institutions separately. Private and public institutions face different competition in the market for investment capital to acquire building space. Private institutions are likely to enjoy easier access to private donations. Public institutions may have access to tax revenue. Opportunities to borrow may also differ between the public and private sectors. Because private and public institutions compete against each other for students, each may find it challenging to maintain a student to space ratio that differs much from the other. We do not speculate on whether private or public colleges and universities are expected to have more students per square feet of building space.

Although our measure of space consists only of the square feet of structures, buildings obviously reside on land. Where land is more expensive, the total cost of building projects is greater, either because the land costs more, or because the buildings are built taller, and each successive floor as a building rises skyward costs more than the floor below it. Land costs are elusive for several reasons. The acreage on which many colleges and universities sit was acquired decades or centuries earlier, and thus there is no market price available. Although the current market price per acre of land adjacent to a college or university could be used to approximate the opportunity cost of land, the price 
of adjacent land undoubtedly is endogenous, depending itself on the presence of the college or university. And land prices tend to vary more within short distances than building prices. Land prices on one side of a university may differ dramatically from land prices on the other side. We make a rudimentary attempt to control for land prices by including a set of binary variables that reflects the location of the institution, ranging from the interior of a large city to urban fringe of a large city, interior of a mid-sized city, urban fringe of a mid-sized city, large town, small town, or rural location. Our expectation is that, in general, land costs decline as one moves from the interior of a large city to a rural location, and therefore the student to square feet of building space ratio would decline as well. In sum, we expect colleges located in small towns and in rural areas to offer students more building space than those located either in the interior or on the urban fringe of metropolitan areas.

\section{Data}

The three key variables in our analysis are student enrollment, square feet of building space, and the price of capital. Students consist of all (undergraduate, graduate, and professional) full-time equivalent students in 1993-94. The student count is derived from the U.S. Department of Education's Integrated Postsecondary Education Data System (IPEDS).

Data on the square feet of building space are collected from the Corporate Costs and Staffing Report for College and University Facilities (CCSR) for 1993-94. The CCSR data are obtained from each participating institution through a survey conducted by the Association of Higher Education Facilities Officers. The survey is sent to the 
office of facilities management at each institution. ${ }^{4}$ Unfortunately, the measure of square feet does not distinguish space used by students from other space. Classroom space, dormitory space, laboratory space, hospital space, and space used by the athletic department are all lumped together. This necessitates segregating the sample into groups of institutions with different missions and attempting to control for differences across institutions in such things as dormitory space.

The price of capital stock is the unit price of capital, derived by dividing the total replacement cost of all buildings by the total gross square feet of building space. It too is obtained from IPEDS. The IPEDS survey asks institutions to report both the book value and the replacement value of buildings. Replacement value of buildings is used as a measure of the aggregate cost of buildings. Dividing replacement value of buildings by gross square feet of building space obtained from CCSR produces the unit cost of space which varies plausibly from an average $\$ 92$ per square foot at two-year colleges to $\$ 108$ per square foot at research universities.

Not all institutions reported the replacement value of buildings, however. In the population of all colleges and universities, 2242 reported both book and replacement values, but 557 institutions reported only the book value of buildings. The 557 missing replacement cost observations were estimated by regressing the replacement values on the book values for the 2242 institutions that reported both [Winston and Yen (1995) and Winston and Lewis (1996)] and predicting replacement values from the book values for the missing observations. ${ }^{5}$

For the remaining variables we obtained the locale of each institution, whether the institution is privately or publicly controlled, and the number of students who could be 
accommodated in college or university provided housing from Barron's Profiles of American Colleges and Universities, $21^{\text {st }}$ edition (1996). Enrollment is the same total full-time equivalent enrollment used as the denominator in the unit price of capital calculation. The growth rate of enrollment is the average annual percentage change in enrollment over the period 1986-87 through 1993-94, calculated by regressing the log of full-time equivalent enrollment in four years (the two reported above plus 1990-91 and 1992-93, all obtained from IPEDS) on time.

\section{Empirical Results}

The empirical estimates are reported in Tables 1-4. The logarithm of the output to capital ratio (students to square feet) is regressed on attributes of each of four types of institutions using ordinary least squares. The dependent variable is specified as a logarithm because the regressors explain substantially more variation in it than in either a linear specification of the student to square feet ratio or a log-log specification of the estimated equation, and we have no theoretical basis on which to prefer one particular functional form to the other. Thus the specification implies that unit changes in the explanatory variables are related to percentage changes in the ratio of students to square feet.

The price of capital is statistically significantly related to the ratio of students to square feet only for two-year colleges. Where space costs more, two-year colleges crowd more students into a given area. The estimated coefficient is also positive for regional state universities, but is statistically significant at only the 0.30 level, substantially below conventionally acceptable tolerance for error. The price of capital appears to have 
virtually no effect on the amount of space available per student at either research intensive universities or selective private liberal arts colleges.

The regression results are erratic. For the two groups of private colleges and universities, the price of capital has no association with the capital intensity of the college. The price of capital has the expected negative effect among private comprehensive universities but a positive association among two-year colleges

Not a single explanatory variable is significant in the estimate for selective private liberal arts colleges, a group of institutions that is fairly homogeneous. There is a 0.90 correlation between students per square foot and faculty per square foot among the liberal arts colleges. The students per square foot appear to be shaped primarily by the wealth of the college. ${ }^{6}$ The adjusted coefficient of determination is negative and the F-ratio indicates that we cannot reject the hypothesis that all coefficients in the liberal arts equation are simultaneously zero. We thus make no claim that we know anything about variation in capital intensity of private liberal arts colleges.

For the public comprehensive universities, the results are encouraging. Our estimates explain 66 percent of the linear variation in the logarithm of the student to square feet ratio for public comprehensive universities. Where enrollments were growing, space per student was falling. Three of the locales also show effect with more space per student in universities in towns and fringes than in large cities. There is no statistically significant effect of scale among the public comprehensives. The point estimates of the coefficients are consistent with space per student falling to an enrollment of 15,000 . 
For the two-year colleges, the price of capital has an anomalous positive coefficient. There is a scale effect with a space per student peaking with an enrollment of 10,719 and diminishing thereafter. The rate of change in enrollment has no effect nor does city size.

The capacity to accommodate more enrolled students in on-campus housing is not associated with aggregate space per student in our estimates. We omit this variable from the two-year college estimate because few two-year colleges offer residences.

To look at the production relationship in a little different way, we examine the relationship between students per square foot and faculty per square. Table 5 reports simple regressions for each of the four groups of institutions. The relationship is quite strong for liberal arts colleges, a result that is consistent with the view the level of college wealth account for space. The relationship is also statistically significant for both private and public comprehensive universities, but modest coefficients. There is no associate for two-year colleges, a finding that may reflect the importance of part-time faculty or wide variation in teaching loads across two-year colleges.

\section{Conclusion}

The evidence we have accumulated suggests that university administrators at public comprehensive universities adjust the amount of building space available to their students on the basis of its relative price. Two-year colleges inexplicably show the opposite effect.

There is no evidence that the two groups of private colleges we analyze pay attention to the relative price of capital in choosing the amount of space they make 
available for their students. In view of the peculiar method of financing buildings at these institutions, this is not surprising. Indeed, financial endowment per student [using the market value of endowment on June 30, 1994, (obtained from the Chronicle of Higher Education, February 16, 1996) is significantly related to students per square foot at both liberal arts colleges and private comprehensive universities. For liberal arts colleges, an additional ten percent endowment is associated with a 1.1 percent reduction in students per square foot. For the private comprehensive universities, a ten percent higher endowment is associated with 2.6 percent more space per student. Interestingly, once endowment is controlled, the space available per student at comprehensive universities or liberal arts colleges is not associated with the price of capital. The price of capital does not appear to affect capital intensity whether controlling for endowment or not. 
Table 1. Sensitivity of Capital Intensity to the Price of Capital: Private Liberal Arts Colleges (Dependent Variable $=\log$ (FTE Students/Gross Square Feet of Buildings)

\begin{tabular}{lrrrl}
\hline \multicolumn{1}{c}{ Variable } & Coefficient & t-ratio & Mean & \multicolumn{1}{c}{ Unit } \\
\hline Intercept & $-2.826^{* *}$ & -7.38 & & \\
Price of capital & 0.000 & 0.30 & 93.13 & \$ per sq. foot \\
Mid-size City & 0.125 & 1.19 & 0.30 & proportion \\
Urban fringe large city & 0.046 & 0.43 & 0.24 & proportion \\
Urban fringe mid-size city & -0.049 & -0.35 & 0.09 & proportion \\
Large town & 0.032 & 0.16 & 0.03 & proportion \\
Small town & 0.033 & 0.27 & 0.21 & proportion \\
FTE (000s) Enrollment & -0.093 & -0.31 & 1543.88 & students \\
FTE (000s) squared & 0.035 & 0.43 & & \\
Enrollment \% change & -0.565 & -0.19 & 0.01 & annual rate \\
Dorm rooms per student & -0.050 & -0.21 & 0.85 & rooms/student \\
\hline
\end{tabular}

$*=$ statistically significant at 0.05 level; $* *=$ statistically significant at 0.01 level.

Number of observations $=33$

Adjusted Coefficient of determination $=-0.16$

$\mathrm{F}=0.57$

Omitted location category $=$ large city

Sample institutions: Agnes Scott, Amherst, Bowdoin, Centre, Claremont McKenna, Holy Cross, Davidson, Denison, Furman, Juniata, Macalester, Pitzer, Pomona, Williams 
Table 2. Sensitivity of Capital Intensity to the Price of Capital: Private Comprehensive Universities

(Dependent Variable $=\log$ (FTE Students/Gross Square Feet of Buildings)

\begin{tabular}{|c|c|c|c|c|}
\hline Variable & Coefficient & t-ratio & Mean & Unit \\
\hline Intercept & $7.372 * *$ & 10.60 & & \\
\hline Price of capital & -0.002 & -1.00 & 90.67 & $\$$ per sq. foot \\
\hline Mid-size City & -0.333 & -1.29 & 0.37 & proportion \\
\hline Urban fringe large city & -0.439 & -1.76 & 0.22 & proportion \\
\hline Urban fringe mid-size city & -0.273 & -0.99 & 0.11 & proportion \\
\hline Small town & -0.373 & -1.06 & 0.07 & proportion \\
\hline FTE (000s) Enrollment & -0.328 & -1.97 & 3788.37 & students \\
\hline FTE $(000 \mathrm{~s})$ squared & 0.021 & 1.85 & & \\
\hline Enrollment $\%$ change & $-6.895 * *$ & -3.02 & 0.03 & annual rate \\
\hline Dorm rooms per student & -0.511 & -1.16 & 0.39 & rooms/student \\
\hline
\end{tabular}

- = statistically significant at 0.05 level; $* *=$ statistically significant at 0.01 level.

- The two coefficients for enrollment are not jointly statistically significant.

Number of observations $=27$

Adjusted coefficient of determination $=0.37$

$\mathrm{F}=2.72 *$

Omitted location category $=$ large city

Sample institutions: Elon College, Stetson University, Mercer University, University of Dayton, Trinity University, Norwich University, Creighton University, Rider University 
Table 3. Sensitivity of Capital Intensity to the Price of Capital: Public Comprehensive Universities (Dependent Variable $=\log$ (FTE Students/Gross Square Feet of Buildings)

\begin{tabular}{lccrl}
\hline \multicolumn{1}{c}{ Variable } & Coefficient & t-ratio & \multicolumn{1}{c}{ Mean } & Unit \\
\hline Intercept & $5.808^{* *}$ & 17.40 & & \\
Price of capital & $-0.003^{* *}$ & -3.09 & 91.72 & \$ per sq. foot \\
Mid-size City & 0.196 & 1.36 & 0.40 & proportion \\
Urban fringe large city & 0.353 & 1.64 & 0.05 & proportion \\
Urban fringe mid-size city & $0.608^{* *}$ & 3.50 & 0.11 & proportion \\
Large town & $0.524^{* *}$ & 2.81 & 0.07 & proportion \\
Small town & $0.468^{* *}$ & 3.07 & 0.29 & proportion \\
FTE (000s) Enrollment & -0.032 & -0.65 & 7027.44 & students \\
FTE (000s) squared & 0.001 & 0.46 & & \\
Enrollment \% change & $-9.213^{* *}$ & -7.40 & 0.03 & annual rate \\
Dorm rooms per student & 0.285 & 0.54 & 0.17 & rooms/student \\
\hline * statistically significant at 0.05 level; ** statistically significant at 0.01 level.
\end{tabular}

Number of observations $=55$

Adjusted coefficient of determination $=0.66$

$\mathrm{F}=11.56^{* *}$

Omitted location category $=$ large city

Sample institutions: Appalachian State, Central Washington, Eastern Michigan, Lamar, Rowan, SUNY-Oswego, Alabama-Huntsville, Wisconsin-LaCrosse, Western Illinois 
Table 4. Sensitivity of Capital Intensity to the Price of Capital: Two-year Colleges

(Dependent Variable $=\log$ (FTE Students/Gross Square Feet of Buildings)

\begin{tabular}{lcrrl}
\hline \multicolumn{1}{c}{ Variable } & Coefficient & t-ratio & Mean & Unit \\
\hline Intercept & $-2.339^{* *}$ & -37.86 & & \\
Price of capital & $0.001^{*}$ & 2.60 & 92.48 & \$ per sq. foot \\
Mid-size City & -0.051 & -1.19 & 0.32 & proportion \\
Urban fringe large city & -0.010 & -0.23 & 0.23 & proportion \\
Urban fringe mid-size city & 0.092 & 1.16 & 0.04 & proportion \\
Large town & -0.112 & -1.06 & 0.02 & proportion \\
Small town & -0.043 & -0.85 & 0.19 & proportion \\
FTE (000s) Enrollment & $0.061 * *$ & 3.77 & 4177.57 & students \\
FTE (000s) squared & $-0.003 *$ & -2.62 & & \\
Enrollment \% change & -0.055 & -0.10 & 0.04 & annual rate \\
\hline
\end{tabular}

$*$ = statistically significant at 0.05 level; $* *=$ statistically significant at 0.01 level. Number of observations $=95$

Adjusted Coefficient of determination $=0.36$

$\mathrm{F}=6.89^{* *}$

Omitted location category $=$ rural

Students/ sq. feet peaks at enrollment of 10,719

Sample institutions: Blackhawk Technical College, Coastal Carolina Community College, Fresno City College, Pima Community College, Temple Junior College 
Table 5 Regressions of Square Feet per Student on Square Feet per Faculty Member

\begin{tabular}{|c|c|c|}
\hline Institution Type & coefficient & R-square \\
\hline Liberal Arts & $289.310^{* *}$ & 0.81 \\
\hline Private Comprehensive & $0.074^{* *}$ & 0.47 \\
\hline Public Comprehensive & $0.048^{* *}$ & 0.70 \\
\hline Two-year & 0.009 & 0.00 \\
\hline
\end{tabular}

- Number of observations is as in tables 1 to 4 . 


\section{References}

Clotfelter, Charles, Ronald Ehrenberg, Malcolm Getz and John Siegfried. 1991. Economic Challenges in Higher Education (Chicago: University of Chicago Press).

Getz, Malcolm, John J. Siegfried and Hao Zhang. 1991. "Estimating Scale Economies in Higher Education,” Economics Letters, Vol. 37, pp. 203-208.

Winston, Gordon. 1993. "Why Are Capital Costs Ignored by Nonprofit Organizations and What Are the Prospects for Change??" Chapter 13 in Michael S. McPherson, Morton Owen Schapiro, and Gordon C. Winston, Paying the Piper: Productivity, Incentives, and Financing in U.S. Higher Education (Ann Arbor: University of Michigan Press), pp. 305-313.

Winston, Gordon and Ethan Lewis. 1996. "Physical Capital and Capital Costs in U.S. Colleges and Universities: 1993," Williamstown: Williams Project on the Economics of Higher Education Working Paper.

Winston, Gordon and Ivan Yen. 1995. "Costs, Prices, Subsidies, and Aid in U.S. Higher Education.” Williamstown: Williams Project on the Economics of Higher Education. 


\section{Endnotes}

\footnotetext{
${ }^{1}$ The authors are Associate Professor and Professor of Economics, respectively, at Vanderbilt University, Nashville, Tennessee. We thank Rob Moore, Tim Schuman, and Michael Gleason for research assistance on this project. Jim Meehan provided helpful comments on an earlier draft

${ }^{2}$ Cost savings may create utility for college and university decision-makers by providing the wherewithal to enhance the quality and prestige of the institution or to boost the institution's allocation to payroll, especially that of the decision-makers.

${ }^{3}$ We have explored a relationship between endowment and students per square foot and find a strong relationship. Colleges with more financial wealth also have fewer students per square foot. We omit endowment from the estimates we report below because endowment may also be associated with higher quality services in a variety of ways, adding ambiguity to the interpretation.

${ }^{4}$ Facilities officers report gross square feet of building space used by the institution. Although the space figures are gross rather than net square feet (the difference is occupied by walls and utilities space that is not usable), the ratio of gross to net square feet is likely to be fairly constant across institutions. Thus differences in gross square feet will accurately reflect differences in net square feet.

${ }^{5}$ Replacement values are estimated as 2.333 times book values. Forty-three of the 230 observations required us to estimate the replacement value from the book value of buildings. A few observations that produced a price of capital more than three standard deviations from the mean were eliminated from the analysis on the presumption of unexplained definitional differences.

${ }^{6}$ The same regression reported in table 1 with the log of endowment included (not reported) shows a statistically significant association with endowment but none of the other variables are statistically significant.
} 